\title{
THE “HIDDEN" ROLE OF THE STATE IN DIFFERENT APPROACHES ON COMPETITIVENESS (THEORETICAL COMPARISON)
}

\author{
Hristina Dobreva ${ }^{1}$ \\ Rakovski National Defence College, Sofia, Bulgaria
}

\begin{abstract}
From the perspective of political science the paper is a comparative overview of some of the main approaches on competitiveness. The focus is on their strengths and weaknesses in the explanation of the role of the government. Yet the paper compares some of the more recent authors as Porter, Reich, Thurow, Ohmae and Strange.

The implication is that government intervention is still needed to provide both sustainable competitiveness (Strange) (modesty as opposed to resource depletion) and social adjustment (jobs) to innovation in the long-term dynamic picture (Porter) because government is still at the basis of the welfare pyramid (Thurow). I start with the authors' assumptions and proceed with their view on the role of the government to conclude that this role is underestimated in the social and overestimated in the business sphere.
\end{abstract}

Keywords: competitiveness theories; state; role of the government; globalization.

\section{INTRODUCTION}

As there is no accepted definition of competitiveness (Porter 1990, xxiv) different interpretations (as mentioned by Harris and Watson) could be found. The competitiveness debate, if driven by a concern about the rate of growth of per capita real incomes, could also be seen as a debate between the mainstream economists and the "the most popular writers on competitiveness", as political scientists, political economists and management theorists, that "come from outside the mainstream" (Harris and Watson 1992, 234) and use grand generalizations ${ }^{2}$. From the perspective of political science the paper is a comparative overview of some of the main approaches on competitiveness. The focus is on their strengths and weaknesses in the explanation of the role of the government. Yet the paper compares some of the more recent authors as Porter, Reich, Thurow, Ohmae and Strange ${ }^{3}$.

Different approaches on competitiveness focus on different key actors: Porter's innovationdriven national economy focuses on firms and the government's role is to encourage firm's competitiveness; Reich and Ohmae's "extremely globalized" national economy focuses on the Multinational corporations (MNCs) and the highly skilled labour as a factor. This approach is close to the neoclassical trade model or the Hecksher Ohlin-Samuelson model. The role of the government is in building strong infrastructure and increasing the professional qualification. Thurow's approach on the other hand is based on Neorealism (strategic trade theory, regionalism) and the main actors are the national governments whose role is to direct capital to key industries. The models of the three aim at increasing the general welfare. Economic growth is based on cosmopolitanism of global citizens through (MNCs), a wealth pyramid (Thurow) or productivity as "the root cause of a nation's standard of living" (Porter 1990a, 617). Porter, Reich and Thurow represent mostly the US approach to

\footnotetext{
${ }_{1}^{1}$ Corresponding author: h.dobreva@rndc.bg

${ }^{2}$ According to Harris and Watson authors as Reich, Porter and Thurow represent this non-mainstream view.

${ }^{3}$ The literature selection is based on ch10 "Multinational Corporations and Global Production ", Theodore Cohn. Global Political Economy: Theory and Practice, Addison Wesley Longman, 2005.
} 
competitiveness. This is not surprising since they have been actively engaged in the US economic policy ${ }^{4}$.

I argue that within the approaches, different interpretations about the role of the government are also possible because in the long-run, dynamic picture, the market factors, exogenous and endogenous to the state, are two complementary approaches and causality runs in both directions (Odell 2000: 68). The longer the lag, the more endogenous (embedded in the country's political economy) the market becomes. All of the authors use both endogenous (resulting from governmental role) and exogenous factors in the explanation of competitiveness. Among the endogenous are: the importance of the home base for domestic rivalry (Porter, Thurow, Pauly and S. Reich). Thus government's role is in education, infrastructure (Porter, Thurow, Ohmae), factor upgrading (Porter), facilitating R\&D spending (Thurow, Ohmae). On the other hand the government is lacking and exogenous forces are at work because of the mobility of all factors (Porter), the rise of geocentric MNCs where ownership does not matter, opposite to the Vernon's cycle model, (Reich, Ohmae), the importance of global citizens and factor-price equilization (Reich, Ohmae), regional blocs (Thurow, Reich) and "symbolic analysts" (Reich). Thus the government becomes invisible (Reich, Ohmae), an "influencer" or just an additional variable in the static structure of the diamond (Porter) and cannot help those unable to compete (Thurow). The analysis on competitiveness is both micro (Porter) and macro (Thurow, Ohmae), both a zero (Thurow) and a non-zero sum game (Porter, Reich, Ohmae). What is implied is that government intervention is still needed to provide both sustainable competitiveness (Strange) (modesty as opposed to resource depletion) and social adjustment (jobs) to innovation in the long-term dynamic picture (Porter) because government is still at the basis of the welfare pyramid (Thurow). I start with the authors' assumptions and proceed with their view on the role of the government to conclude that this role is underestimated in the social and overestimated in the business sphere.

\section{METHODOLOGY-ASSUMPTIONS OF THE AUTHORS}

Porter's approach is based on the firms' decisions to compete in a global economy. While factors as labour, natural resources and financial capital explain the comparative advantage of nations in the $18^{\text {th }}$ and $19^{\text {th }}$ century ${ }^{5}$, increased factor mobility (Porter 1990a, 15) shifts the importance to factors as the creation of business environment, specialization in the form of clusters ${ }^{6}$ and the locational advantage, or firms' best choice of location for productivity, especially in industries involving sophisticated technology and highly skilled employees. Increase in knowledge-intensive industries after the WWII, (Porter 1990a, 13) increases the importance of competitive advantage based on the differentiation of production. Competitiveness and national advantage, as equal to industry's competitive advantage (Porter 1990a, 282), are based on the "diamond "(Porter 1990a, 72) as a system of four basic interrelated variables from the firms' perspective (the factors of production, home demand, firm's strategy and related and supporting industries) and two additional variables (governments and the chance factor). Domestic rivalry leads to improvement and geographic concentration, increases the interaction of the four variables and transforms the diamond into a system (Porter 1990b, 83).

In Reich's approach not all factors are equally mobile, the labour force being least so, relative to capital and technology. The skilled work force attracts foreign investment (Reich 1990, 59) and improves the country's standard of living generating a virtuous cycle of additional investment for education. This is vital especially with the tendency of the government (Reich means the American

\footnotetext{
${ }^{4}$ Porter, previously appointed by President Reagan to the President's Commission on Industrial Competitiveness, is a member of the Executive Committee of the Council on Competitiveness, which is a private-sector US organization and also with Jeffrey Sachs have created the Global Competitiveness Report. Reich has served as secretary of labour under President Clinton. Thurow has served in the President's Council of Economic Advisers in the mid sixties and the Economic Advisory Council in the late 70ies.

${ }^{5}$ The theories of Adam Smith (absolute advantage) and David Ricardo (comparative advantage) are among the authors that contribute to liberal theories of free-trade. Adding capital to the labour factor in the explanation of country's comparative advantage leads to the Hecksher-Ohlin theory (Cohn 2005, 223).

${ }^{6}$ Specialization is required for production. The cluster is a group of interconnected firms, suppliers, related industries and specialized institutions in a given field (Porter 1990, xii).
} 
government) to retreat from the field of education?. Contrary to Porter, Reich's corporations are geocentric (Perlmutter 1969, 12), "disconnected from their home nations" (Reich 1991, 8). Nation's competitiveness is based not upon corporation ownership but upon differentiation of nation's labour skills and the value added to the world economy in this way (Reich 1991, 168). The national policy has to reward any global corporation that invests in the nation or the state should help corporations achieve economies of scale, "regardless of their nationality" (Reich 1990, 62) because these corporations increase the nation's standard of living.

Reich's approach is based on the global citizen. Human capital or the educated labour force is the most important element, opposed to Porter's focus on innovation. This human capital will be cosmopolitan but international cooperation comes as a second responsibility and the "primary responsibility" of the global citizen (Reich 1991, 312) is in improving the nation's well-being. Thus cooperation is based on rational self-interest (American model), not on altruism. Reich assumes, similar to the neoclassical trade Hecksher-Ohlin model of international trade, that the same technologies are available in all countries and identical factors of production, regardless of their location receive the same economic return. Thus a regime of free trade leads to "factor-price equalization", even if factors do not move, (Harris and Watson 1992, 252). Despite of the increase of intra-firm trade (Harris and Watson 1992, 254) however, in the neoclassical trade model, international trade can on its own lead to factor-price equalization, regardless of the patterns of firms' international investment.

Ohmae's explanation of globalization focuses on the "global localization" thesis (Ohmae 1991, 8) where firms operate globally but through local companies and markets and regional clusters of activity. Ohmae's approach is macroeconomic but the game is not a zero-sum. This is a cooperative competition organized around a "strategic triangle" of customers, competitors and company (Ohmae $1991,2)$ but also taking into consideration the currency exchange rates and the country. In other words companies have to become embedded in the country in order to neutralize the impact of currency and protectionism. This is a model for MNCs, opposite to Vernon's model and more relevant since the 1980s - the MNC expands into the country and follows the needs of the local customers (Ohmae 1991, 31) ${ }^{8}$.

Thurow's approach focuses on the competition at the beginning of the $21^{\text {st }}$ century as a zerosum game ("head-to head" competition) because each region wants the same industries, and the regional blocs are the main players. This competition is opposed to the "niche" competition (Harris and Watson 1992, 258) typical for the early postwar years when GATT was created. However a niche competition is still possible within the industries. The focus is on research and development spending because "technological leaders remain economic leaders " (Thurow 1993,188) and industries which will define national success in the third industrial revolution will be "microelectronics, biotechnology, telecommunications, civilian aviation, robotics ...computers " (Thurow 1999, 5). Contrary to Reich's idea, but similar to Porter, the firms have to remain national institutions for the national standard of living to rise.

\section{RESULTS}

\section{The "Hidden" Role of the Government}

In Porter the home business environment and consequently "ethnocentric" MNCs (Perlmutter $1969,12)$ are most important for the firms' success. The government's role is to create the environment for competition by providing the education and infrastructure. The role of the government is different in the different stages of competitive development and different states remain at different stages $^{9}$. In the first (factor-driven) stage basic factors ${ }^{10}$ as natural resources, location and semiskilled

\footnotetext{
${ }^{7}$ Reich mentions that George Bush's 1990 education budget is smaller than Reagan's in 1989 (Reich 1990, 64).

8 Vernon also admits a change in the applicability of the product-cycle hypothesis since 1970s (Vernon 1981, 519) because of the convergence in the factor costs in the US, Europe and Japan.

${ }_{9}^{9}$ For example all developing and centrally planned economies as well as nations with bountiful resources as Canada and Australia are said to remain at stage one (Porter 1990, 548).

${ }^{10}$ Communications, infrastructure, highly educated personnel and research institutes are considered to be advanced factors (Porter 1990, 77).
} 
labour (Porter 1990, 77) are source of the advantage. In the second (investment-driven) stage, although firms are the risk-takers, the government promotes risk-taking by directing the investments to particular industries and thus upgrading the factors (Porter 1990, 551). Governments provide the national consensus required for the long-term economic growth, or a commitment to improve factor quality. In fact it seems that stage two is government-driven which boosts the innovation-driven (third) stage where firms and private sector predominate and the government role becomes indirect. In the static picture the government influences the factor conditions through subsidies and policies towards education, the demand conditions through product standardization and government expenditure, the supporting industries through regulation of supporting services and firm strategy through capital regulations, tax policy and antitrust laws (Porter 1990, 128). However, the government is stronger because it can "pick clusters" and winners (Harris and Watson 1992, 250).

In the Reich's case government role is observed comparing US capitalism in the middle of the $20^{\text {th }}$ century and in the future. In the mid $20^{\text {th }}$ century the role of the American government was based on a national bargain, a "tacit agreement" (Reich 1991, 68) between the business and labour and the aim was economies of scale but also growing middle class $^{11}$ and welfare. The direct role of the government was in the provision of education, home subsidies, infrastructure, defence spending and encouragement of the companies to invest abroad. The indirect role was in the lack of centralized economic planning and non-intervention in the private corporate planning for research and development. Compared to this view, his idea about the future role of the government suggests a third, more modest way between the zero-sum nationalism and the laissez-faire cosmopolitans. According to this third way, not all government intervention should be avoided and its central role is the education of the labour force, improvement of the infrastructure and creation of "international rules of fair play" (Reich 1991, 312) because the most important asset of the nation becomes the skills and learning of its work force (Reich 1990, 58).

While Porter and Reich focus mainly on the US model, Thurow argues that the three different forms of capitalism (US, Japan and EU or Germany) are based on different history because Germany and Japan had to catch up with the US and the UK. Compared to the US, the government in Europe and Japan has bigger role in economic growth and the linkage between economic and military strategies is more evident, the line between the public and private disappears (Thurow 1993, 35) ${ }^{12}$. Governments manage trade, which leads to the increase of bilateral negotiations not in line with the most-favoured nation's principle of free trade. Government's role is in encouraging investments in skills, infrastructure and research and development.

Similar to Thurow, Pauly and Simon Reich ${ }^{13}$ focus on the difference of national structures, distinctive ideological traditions and national histories, embodied in the national, slowly-changing institutions that provide the framework and shape the corporate decisions of MNCs (Pauly and Reich $1997,1)$. Evidence suggests that there is little blurring at the cores of firms based in the three regions, referred as the "Triad", namely Germany ${ }^{14}$, Japan and the United States. The three structural ideal types are the US liberal democracy with free enterprise liberalism, the German's social democracy, or "social market economy" (Thurow 1993, 36) and the Japan's developmental democracy and technonationalism. The market adaptation of the firm depends on its nationality (Pauly and Reich 1997, 4).

\section{A Lack of Government Where More Government Is Needed}

Although the title of Porter's book suggests a focus on nations, the focus is on companies and the competition in industries. Although the government has a two-way relation with all the four components of the diamond, its role is that of a positive or negative "influencer" (Porter 1990, 128) and remains partial. Although the government could be one source of innovation (Porter 1990, 47) or

\footnotetext{
${ }^{11}$ This agreement resembles Ruggie's "embedded liberalism" agreement.

${ }^{12}$ Airbus is an example of a Pan-European strategy, where a civilian manufacturer is owned by the British, French, German, and Spanish governments (Thurow 1993, 35).

${ }^{13}$ They base their structuralism on Katzenstein, Garrett, Krasner. This is referred in footnote 20 on p. 6 of their article.

${ }^{14}$ German base is the analog to the American and Japanese cases because of Europe's top one hundred firms, twenty-seven are German (Pauly and Reich 1997, 6).
} 
a factor-creating mechanism (Porter 1990, 80) it is not a central but an additional variable in the diamond, a part of the diamond's environment. Although the home base is important, a firm may have different home bases for different businesses (Porter 1990, 614).

The nation is just a "region of the global economy" (Reich 1991, 244). The lines of the nations are blurred as a result of technology and interdependence and the key players and citizens of the world are the MNCs where control and "ownership" are "less important" (Reich 1990, 56). Governments and the national boundaries become invisible (Ohmae 1991, 183), "transparent" (Ohmae 1991, 12) and not protecting industries. This is a kind of bottom-up governance serving the people, not imposing on them its policy.

The government should not be disregarded for the provision of sustainable competitiveness or creating patterns of advantages, and its role is more important in the dynamic, long-term picture. Porter is against the inertia and considers governments slow (Porter 1990, 81) because governments favour policies leading to short-term, static benefits that undermine innovation and dynamism. However, he does not consider a possibility of supplementing his innovation-driven ${ }^{15}$ diamond with another diamond where governments may provide the continuity or social adaptability to innovation. The government may add modesty to innovation because resources are limited. The enforcement of strict safety and environmental standards aims at improving of the quality but does not create modesty and more depletes the resources of the first stage. The competitive advantage emerges out of pressure or rivalry (Porter 1990,174) and resembles in this way the Schumpeter's idea of "creative destruction"16, an idea used also in Thurow's knowledge-based capitalism (Thurrow 1999, 83) but there is no time for adjustment in this way. Thus the government is a "challenger" (Porter 1990b, 86) for higher level of companies' competitiveness and should encourage change, promote domestic rivalry and stimulate innovation. In Porter's diamond causality can run in both directions (Stopford and Strange 1991, 9). Porter's rational framework does not elaborate on the dynamic processes because the diamond is profit, not human-resource driven (where governments could create knowledge societies).

Government's role in education is a prerequisite for the global society to work As Reich's cosmopolitanism is based on the American rational model (Reich 1991, 68), the impression is that the global educated labour force will come from certain regions only, mainly America, EU and Japan who have had the "national bargain" (Reich 1991, 68) as a prerequisite. However, as this education is nation based and in light of the phenomenon of "relative deprivation"17 (Reich 1992, 308) or neomercantilism produced by interdependence, it is not clear who will take the responsibility to educate the world society of solidarity and cosmopolitanism and whether the economic interdependence will naturally produce global citizens convinced of the necessity of cosmopolitanism. In other words, Reich does not explain how the ideal of cosmopolitanism will be produced and how the geocentric multinational firm has coped with problems as economic nationalism and trust-building (Perlmutter 2001, 18). Reich does not explain how the "future symbolic analysts" (Reich 1991, 309) or extreme globalists, and more precisely "symbol manipulators" (Harris and Watson 1992, 253, n30) will appear, what their predominantly American background implies (Reich 1991, 178) ${ }^{18}$, how the global obligations will be shared.

Thurow does not take into consideration that government policies may not always work in favour of the national interest but in favour of private interests. Government's role seems to be at the basis of the wealth pyramid for the maintenance of the social organization through provision of public order, infrastructure, education and health. However wealth is generally based on knowledge and the problem is that ownership of knowledge is a "slippery concept" (Thurow 1999, xv). At the same time governments lose their ability to help those who cannot compete successfully. In short the economic game will be played on three levels: nations, companies and individuals (Thurow 1999, 97). It is

\footnotetext{
15 The increase in firms' rivalry leads to increase in innovation (Porter 1990, 157).

16 "Creative destruction" (Stolper 1994, 61) is replacement of the old with new technologies, as a result of local rivalry and entrepreneurship. This is an idea of establishing a new structure of the economy by a process of integration.

17 "Relative deprivation " is when people evaluate their well-being in light of others' wealth.

${ }^{18}$ Reich only mentions that most of them are white males, and the number of blacks and Hispanics is increasing (Reich 1991 , 179). However it is likely that Americans will continue to excel at symbolic analysis (ibid:225).
} 
interesting that the three main regions are building wealth being at different levels of the wealth pyramid (Thurow 1999, ch.13) ${ }^{19}$ : Japan has to build a new structure and start at level one, the government's main role being the debt elimination, Western Europe is to create entrepreneurial environment without destroying the social welfare state, America has to work on skill-building and is closest to the top of the pyramid. A global economy replaces the national economies but there is no global government to replace the national governments. In this way no-one is responsible for maintaining a global wealth pyramid and firms are the "global or niche players" (Thurow 1999, 279).

Ohmae suggests that global corporations are "nationalityless" (Ohmae 1991, 195) and he bases this on the levelling of consumers' tastes, or the global product approach producing commonalities (Ohmae 1995, 26). Government's role is to create environment for the MNCs, not to protect against them but also the role of the government is to "represent and protect the interest of its people, not of its companies" (Ohmae 1991, 201), educate the people and let them decide which is good. The invisible continent has no government and resembles a "frontier environment" (Ohmae 2000,215 ) where the fights are between speculators (risk-takers) and governments, responsible for the well-being of the people. However, it is not clear whether governments will intervene more to protect their citizens if conflict of interest arises between them and the MNC and whether it is possible for the government to educate its people without influencing them when education is the fundamental lever for success and starts at home as the first priority of any nation. The author's view of "one big happy family" (Ohmae 1991, 213) in the interlinked economy is a generalized talk about the future with focus on "cross-cultural alliances" (Ohmae 1995, xv) ${ }^{20}$. On the other hand, although the companies do not approach states but regional markets still the home region is important and worldwide competitors have first attained "status of domestic giants" (Ohmae 1995, 45). The bloc competition is company-based and the company's strategy is to simultaneously and mainly through consortia alliances with regional corporations, become an "insider or honorary citizen" in the three main economic blocs, called "Japan-European Community-United States syndicate " (Ohmae 1995, viii) and thus become a triad power with strong holds in the regions south of its geographic region ${ }^{21}$.

\section{Additional Criticisms and Further Suggestions}

Historical structuralism offers bottom-up governance as a solution opposed to the "neoliberal hegemonic structures of global capitalist economy" (Cox 1997, 253), and to the "hyper-liberal form" (Cox 1997, 256) of capitalism in North America and Britain. Cox seems to combine Reich's idea on cosmopolitan society, resting on collective responsibility and cross-cultural understanding (in Cox's case) and Thurow's regionalism based on different forms of capitalism. The "new realism" called also "new multilateralism" and "new regionalism" (Cox 1997, 245) is realism with normative goals, focusing on the social cleavages, generated by globalisation, between a dominant trans-national class and subordinate social groups. It seems that Thurow's social order (in the wealth pyramid) is imposed from the top-down, as Cox would suggest the European "civil society " was built, while Reich's is from the bottom-up, as Cox suggests the American "civil society" was built, by a process building counterhegemony through popular participation. Thus Reich resembles Gramsci's idea of a social order, grounded in civil society where the state is "political society + civil society" (Cox 1999, 4) and the human agency is important. In Cox's case however, solidarity is based on "strategy of class alliance" where "the war of position" (Cox 1999, 16) replaces the political authority in the long-run. Unlike Reich, Cox (the Gramscian view) is against competitiveness because it "justifies the gradual removal of the measures of social protection build up in the era of the welfare state" (Cox 1999,12) and imposes neo-liberalism as a hegemonic ideology.

\footnotetext{
${ }^{19}$ Wealth is at the top of Thurow's pyramid, starting from the bottom the levels are as follows: social organization, entrepreneurship or individual initiative, creating knowledge, skills, tools, environmental resources.

20 Samuel Huntington makes similar generalizations, although in the opposite direction, about the clash of civilizations or cultures.

${ }_{21}$ Thus the Japanese Triad power is operative in the US, EC, and Southeast Asia but Japan is at its centre and the Triad becomes a Tetrahedron. In the same way the American includes the US, Japan, EC, Latin America and the European consists of Europe, US, Japan and Africa/Middle East. Latin America is the US biggest trading partner, Southeast Asia is Japan's, Africa is EC's and Middle East is the "common battleground" for all (Ohmae 1995, 122).
} 
Krugman similarly argues that competitiveness is a metaphor used as a "political device" (Krugman 1994, 40), which is more dangerous to apply to nations than to corporations because "the concept of national competitiveness is elusive" (Krugman 1994, 31) and could result in protectionism and wasteful spending of government money. Both Thurow and Reich are not right, he argues. He backs his argument with statistical data showing that US industries with high value-added per worker are capital-intensive (like cigarettes and petroleum refining, computers, aerospace) as opposed to labour-intensive and consequently cannot increase the standard of living. Consequently competitiveness has more to do with political speculation than with productivity and increase of the standard of living. Another criticism of the "evolved capitalism" (Cox 1999, 17) in Europe and America is the contradiction or positive relation between the extension of consumer demand and resource depletion.

In this line Strange is concerned about "sustainable growth", provided not by a strong but a "shrewd state" (Stopford and Strange 1991, 218) with clear vision of priorities. Strange treats the globalising (neoliberal) forces as a fact of contemporary realism. The role of states is to "act as good landlords" (Strange 1998, 113), occupying a territorial space but no longer in control of that place, both providing a market for goods and services and assuring the investors that their space can provide services as transport, communication, personal security and education, R\&D necessary to business managers. There is a relative decrease of states' power because the factors the states control (land and labour) have relatively less importance as determinants of competitiveness, compared to factors as capital and technology controlled by firms. Consequently governments "as a group" (Stopford and Strange 1991, 215) have lost their negotiation power to MNCs but state-firm collaboration is possible if states liberalize their regulations (Stopford and Strange 1991, 96) in line with the international structures formed by industries and firms.

With Reich and Ohmae also it is not clear whether they over or under-socialize. In historical structuralism the economic actor is "embedded in structures of social relations" (Granovetter 1985, 481) but the paradox in both realism (Porter) and liberalism (Reich/Ohmae) is that they tend to atomize or, under-socialize the actor although based on opposite grounds: as a "state of nature" in Hobbes' realism and as a prerequisite to perfect competition in Adam Smith's laissez-faire classical liberalism. With Ohmae's suggestion about levelling of consumer's tastes, there is also atomization as a result of over-socialization where the behavioural patterns have been internalized and "ongoing social relations have only peripheral effects on behaviour" (Granovetter 1985, 485).

\section{CONCLUSIONS}

In the different approaches (placed on a continuum) the level of government intervention is different. Ohmae/Reich's view is that of the long-run future of "extreme globalization"(Harris and Watson 1992, 251) while Porter's firm and Thurow's region base their competitiveness on the home markets, which is close to the realists' view. Thus the government's role (in Porter and Thurow) ranks high in the help of their own MNCs. Like institutional liberals, Reich/Ohmae argue that "the mobility of MNCs gives them a major advantage over national governments" (Cohn 2005, 314) and the ownership does not matter. Government's role rank high on another scale-that measuring help for its citizens to maintain an attractive environment for any MNC (Cohn 2005, 340). Cox's historical structuralism agrees with liberals on the increasing role of MNCs but attribute this as a feature of the capitalist system.

Which approach is better for the future is not the right question because none of them alone can explain the complex reality of interdependence. All approaches generalize/overemphasize in their starting points, focusing either on firms (Porter), individual workers (Reich), individual consumers (Ohmae), states (Thurow). It is interesting that in terms of the evolutionary movement "from ethnocentrism to polycentrism to geocentrism" (Perlmutter 2001,17) a focus on the polycentric type of MNC is missing in the Porter-Thurow- Reich approaches and, observed as a whole they jump from the ethnocentric (Porter) to the geocentric (Reich) type of explanation. This disregards the nationality and cultural impact of the host country because of the increased mobility of factors, a feature, by contrast addressed in Cox's "new realism" approach. Yet a problem remains of how sovereign states 
will deal with the fact that many of their enterprises conduct other sovereigns' influence (Vernon 1981, 529).

The literature focuses more on the economic (supply and demand) than the political implications (internal, dynamic government role, embeddedness) of competitiveness. The different approaches do not explain how is it possible for the government to simultaneously create a business environment and a welfare state (a problem mentioned by Cox and Strange). It seems that sustainability, caring about the citizens and mitigating the effects of the MNCs is a task that contradicts government's role for maintaining a business-friendly environment. From the standpoint of political science government's priority is to provide economic growth/productivity and increase in the standard of living, to find the balance between the exogenous and endogenous factors of growth.

According to more contemporary authors as Jean Tirole competition policy in the digital age involves public intervention, contestable monopolies, efficient rivals in the market, and firms. Contestability or the ability to enter or leave the market freely is of key importance. Paul Romer integrates technological innovation in the long-run macroeconomic analysis as they are important in the process of economic growth. Other important factors are both imperfect competition and externalities to the discovery of new ideas. Innovation is driven by the profits originating from monopolistic competition. According to Paul Krugman, the whole doctrine of "competitiveness" is wrong as nations are not in economic competition. The result of this wrong perception leads to misallocated resources, trade frictions and bad domestic economic policies.

In my opinion economic growth and competitiveness have to be backed by a soumd government policy. Government intervention, through the creation of economic stimuli is the answer to having a true national element in the international market. Governments are the agents that should provide the balancing factor in the equation. In the contemporary digital age I agree with Tirole that public intervention has to provide the contestability of the market. Also, as Romer suggests, new ideas will have an increasing impact on innovation and respectively on competitiveness. However I disagree with Krugman that the notion of competitiveness is outdated. Economic competitiveness based on competitiveness of ideas is vital for the future development of the area.

\section{REFERENCES}

Cohn, Theodore. 2005. Global Political Economy: Theory and Practice, Addison Wesley Longman.

Cox, Robert. 1997. "Reconsiderations" in The New Realism, Perspectives on Multilateralism and World Order, Robert Cox, edt., United Nations University Press, UK.

Cox, Robert.1999. "Civil society at the turn of the millennium: prospects for an alternative world order", Review of International Studies, Vol. 25, 3-28.

Granovetter, Mark 1985. "Economic Action and Social Structure: The Problem of Embeddedness", American Journal of Sociology, Vol.91, No 3, 481-510.

Harris, Richard and William Watson. 1993. "Three Visions of Competitiveness: Porter, Reich and Thurrow on Economic Growth and Policy", in Productivity, Growth and Canada's International Competitiveness, Thomas Courchene and Douglas Purvis, eds., Kingston: John Deutsch Institute for the Study of Economic Policy.

Krugman, Paul. 1994. "Competitiveness: A dangerous Obsession", Foreign Affairs, March-April, 28-44.

Odell, John. 2000. Negotiating the World Economy, Ch.3 Market Conditions, Cornell Univ. Press.

Ohmae, Kenichi. 1991. The Borderless World, Power and Strategy in the Interlinked Economy, HarperBusiness.

Ohmae, Kenichi. 1995. Triad Power, The Coming Shape of Global Competition, The Free Press. 
Ohmae, Kenichi. 2000. The Invisible Continent, Four Strategic Imperatives of the New Economy, Harper Business, New York.

Pauly, Louis and Simon Reich. 1997. "National Structures and Multinational Corporate Behaviour: Enduring Differences in the Age of Globalization“, International Organization, Vol.51, No.1, 1-30.

Porter, Michael. 1990a. The Competitive Advantage of Nations, The Free Press, New York.

Porter, Michael. 1990b. "The Competitive Advantage of Nations", Harvard Business Review, MarchApril, 73-93.

Perlmutter, Howard. 1969. "The Tortuous Evolution of the Multinational Corporation", Columbia Journal of World Business.

Reich, Robert. 1990. "Who Is Us? “,_Harvard Business Review, Jan.- Feb.

Reich, Robert. 1991. The Work of Nations, Preparing Ourselves for the $21^{\text {st }}$ Century Capitalism, Alfred Knopf, New York.

Stopford, John, Susan Strange, John Henley. 1991. Rival States, Rival Firms, Competition for World Market Shares, Cambridge Univ. Press.

Strange, Susan. 1998. "Who are EU?, Ambiguities in the Concept of Competitiveness," Journal of Common Market Studies, Vol.36, No.1, 101-114.

Thurow, Lester. 1993. Head to Head, The Coming Economic Battle Among Japan, Europe, and America, Warner Books.

Thurow, Lester. 1999. Building Wealth, The New Rules for Individuals, Companies, and Nations in a Knowledge-Based Economy, HarperCollinsPublishers.

Vernon, Raymond. 1971. Sovereignty at Bay, The Multinational Spread of U.S Enterprises, Basic Books.

Vernon, Raymond. 1981. "Sovereignty at Bay Ten Years after", International Organization, Vol.35, No.3, 517-529. 